\title{
The relevancy of patch testing in the exploration of the cutaneous side effects of herbal medicine
}

\section{Birame Seck1, Mame Tene Ndiaye1, Assane Diop1, Cheikhouna Gaye², Astou Diouf1, Fatou Gueye Diagne', Fatou Diassé ${ }^{1}$, Djibril Fall', Fatimata Ly' ${ }^{1}$}

\author{
${ }^{1}$ Department of Dermatology, Hospital Institute of Social Hygiene (IHS), Dakar, Senegal, ${ }^{2}$ Department of Pharmacy, Cheikh
} Anta Diop University (UCAD), Dakar, Senegal

Corresponding author: Dr. Birame Seck, E-mail: bir.seck@yahoo.fr

\begin{abstract}
Background: Data on the cutaneous side effects of herbal medicine is scarce, especially with regard to allergy skin testing. Our objective was to determine the relevancy of patch testing in the exploration of the cutaneous side effects of herbal medicine. Material and Methods: A prospective study was conducted in the Department of Dermatology of the Hospital Institute of Social Hygiene of Dakar over a one-year period. Patch tests were given to patients with cutaneous side effects related to the exclusive use of herbal medicine. The plants recovered were turned into macerates and powders and mixed with Vaseline at concentrations of 5\%, 20\%, and 30\%. Results: Patch tests were given to 31 of the 53 patients included. They were positive in 11 patients (35.48\%). Positive patients displayed systemic eczema $(n=7 / 15$ of cases), Stevens-Johnson syndrome $(n=2 / 3)$, contact eczema $(n=1 / 1)$, and fixed pigmented erythema $(\mathrm{n}=1 / 2)$. Positive tests were obtained for 11 medicinal plants identified: Jatropha chevalieri $(\mathrm{n}=2)$, Terminalia avicennoïde ( $\mathrm{n}=2$ ), Detarium microcarpum, Acacia seyal, Acacia albida, Acacia italic, Sesamum indicum, Mangifera indica, Momordica charantia, Nauclea latifolia, and Anogeisius leiocarpus (in one case each). There was no statistically significant relationship between the type of cutaneous side effect and the test result $(\mathrm{p}=0.388)$ and between the nature of the plant used and the test result $(\mathrm{p}=0.402)$. Conclusion: In view of their high rates of positivity, patch tests could prove promising in the exploration of the cutaneous side effects of herbal medicine.
\end{abstract}

Key words: Herbal medicine; Patch tests; Cutaneous side effects

\section{INTRODUCTION}

Despite scientific advances in modern medicine, the World Health Organization (WHO) estimates that $80 \%$ of the African population continues to use traditional medicine in primary health care [1]. In Senegal, most of the population has been moving toward unconventional medicine to treat various diseases, with rates up to $90 \%$ in some locations [2]. The extent of the use of herbal medicine and the potential severity of the possible cutaneous reactions are well known, but few studies have been devoted to this subject, particularly with regard to allergy skin testing. Patch testing plays a major role in the diagnostic approach to cutaneous adverse drug reactions caused by conventional drugs, often establishing a causal link between drug intake and the occurrence of cutaneous adverse events. Their sensitivity can reach $70 \%$ depending on the type of cutaneous reaction and the nature of the drug involved $[3,4]$. We conducted this study in order to determine the frequency of positive patch tests in cutaneous adverse effects related to herbal medicine and to search for a link between test results and the type of cutaneous reaction or the variety of medicinal plant administered.

\section{MATERIAL AND METHODS}

The following is a cross-sectional, descriptive, and analytical study with a prospective data collection

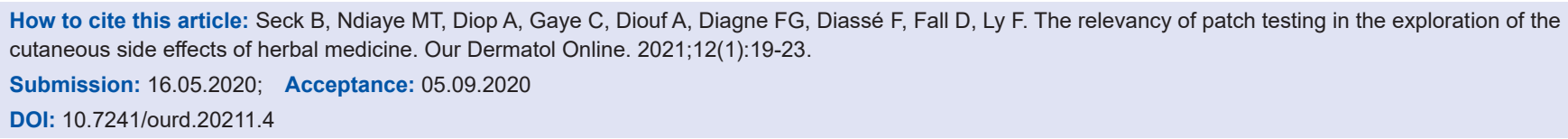


conducted from May 1, 2016, through June 1, 2017 (i.e., for almost one year), in the Department of Dermatology of the Hospital Institute of Social Hygiene of Dakar in collaboration with the Laboratory of Organic and Therapeutic Chemistry of the Faculty of Medicine, Pharmacy and Odontology of Cheikh Anta Diop University of Dakar. Included were cases of a cutaneous reaction related to the exclusive use of herbal medicine. Inclusion necessitated a voluntary informed consent from each patient. Patients who had, at the time of the study, been taking a conventional drug were excluded. All patch tests were free of charge. Each plant recovered was both pulverized and macerated in an acetone extract. The substrates obtained (powder and macerate) were mixed with Vaseline at concentrations of $5 \%, 20 \%$, and $30 \%$. Ointments were packaged in labeled syringes. Some plants were brought by patients in solution form; these were tested as delivered. Patch tests were performed at least 6 weeks after the disappearance of cutaneous reactions. Finn Chambers cups were used as a support system for allergenic ointments and were applied on the back in occlusion. In the case of fixed pigmented erythema, tests were also applied to lesion sites. The lecture of the tests was performed at $48 \mathrm{~h}$ and $72 \mathrm{~h}$. The criteria used were those of the ICDRG (Table 1). Test relevance was always verified. Data was stored in an Excel file and analyzed using the software Stata 14. First, a descriptive study of quantitative and qualitative variables was made, followed by an analytical study. A Pearson's chi-squared test was used to search for a correlation between the dependent variable (positive patch test) and the covariates. The significance threshold was at $\mathrm{p}<0.05$.

\section{RESULTS}

53 patients were enrolled in the study. The average age was 45 years old with the minimum and maximum age of 5 years and 75 years, respectively. The sex ratio was 0.77 . A personal history of atopy was reported in

Table 1: Reading criteria of the ICDRG [13]

\begin{tabular}{lll}
\hline Symbol & Morphology & Assessment \\
\hline- & No reaction & Negative reaction \\
$?+$ & Faint erythema only & Doubtful reaction \\
+ & Erythema, infiltration, & Weak positive reaction \\
& possibly papules & \\
++ & $\begin{array}{l}\text { Erythema, infiltration, papules, } \\
\text { vesicles }\end{array}$ & Strong positive reaction \\
& Intense erythema, infiltrates, & Extreme positive \\
+++ & $\begin{array}{l}\text { coalescing vesicles } \\
\text { Various morphologies, e.g., }\end{array}$ & $\begin{array}{l}\text { Irritant reaction } \\
\text { IR }\end{array}$ \\
& soap effect, bullae, necrosis & \\
\hline
\end{tabular}

(c) Our Dermatol Online 1.2021
24 patients $(45.28 \%)$ with allergic rhinitis $(n=6)$, atopic dermatitis and asthma $(\mathrm{n}=5$ each), and an association of at least two allergic diseases $(n=8)$. An observation of allergy to penicillin $(\mathrm{n}=2)$ and nonsteroidal anti-inflammatory drugs $(\mathrm{n}=1)$ was also reported. The most common cutaneous adverse effects were systemic eczema in 22 patients (Fig. 1), contact eczema $(n=4)$ (Fig. 2), erythrodermic syndrome $(n=4)$ (Fig. 3), fixed pigmented erythema $(\mathrm{n}=3)$, lichenoid rash $(\mathrm{n}=3)$, and Stevens-Johnson syndrome $(\mathrm{n}=3)$. An aggravation of a preexisting dermatosis was noted in 9 patients, including 6 cases of psoriasis. The average time of onset after the administration of the plants was 12 days. Table 2 shows the frequency of the various cutaneous adverse effects with the average time of their onset. Of the 104 plant medications brought by patients, 74 were identified. Those administered most often were Detarium microcarpum $(\mathrm{n}=12)$, Momordica charantia

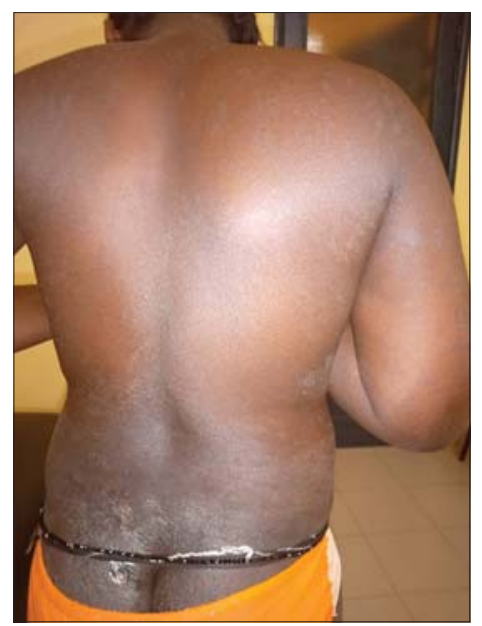

Figure 1: Systemic eczema 7 days after taking Cassia italic.

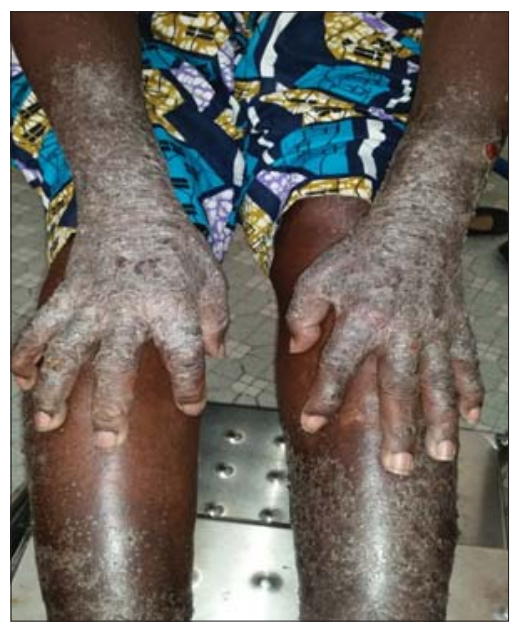

Figure 2: Contact eczema 3 days after the application of an unidentified powder. 
$(\mathrm{n}=7)$, Stereospermum kunthianum $(\mathrm{n}=6)$, Jatropha chevalieri $(\mathrm{n}=5)$, Anogeissius leiocarpus $(\mathrm{n}=4)$, Acacia seyal $(\mathrm{n}=4)$, Euphorbia balsamifera $(\mathrm{n}=4)$, and Terminalia avicennoïde $(\mathrm{n}=3)$. Table 3 shows the distribution of plants according to the type of cutaneous reaction induced. Patch tests were given to 31 patients with 49 plant medications, 8 of which were unidentified solutions. The 31 patients tested displayed the following cutaneous adverse effects: systemic eczema $(\mathrm{n}=15)$, contact eczema $(\mathrm{n}=1)$, Stevens-Johnson syndrome $(\mathrm{n}=3)$, erythrodermic syndrome $(n=2)$, fixed pigmented erythema $(n=2)$, lichenoid rash $(n=2)$, phytophotodermatitis $(n=1)$, and aggravated psoriasis $(n=5)$. Patch tests were

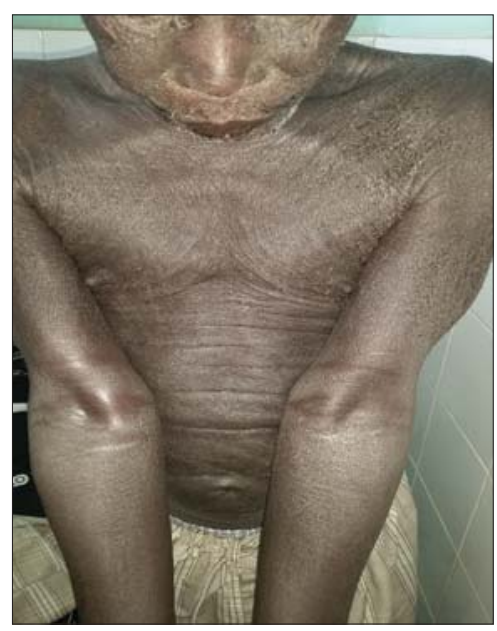

Figure 3: Erythrodermic syndrome 30 days after taking Detarium microcarpum.

Table 2: Distribution of cutaneous side effects with the average time of their onset

\begin{tabular}{lccc}
\hline Cutaneous reactions & $\begin{array}{c}\text { Effective } \\
\text { (n) }\end{array}$ & $\begin{array}{c}\text { Frequency } \\
\text { (\%) }\end{array}$ & $\begin{array}{c}\text { Average time of } \\
\text { onset (days) }\end{array}$ \\
\hline Systemic eczema & 22 & 41.50 & 16.43 \\
Aggravated psoriasis & 6 & 11.32 & 13.33 \\
Contact eczema & 4 & 7.54 & 6.75 \\
Erythroderma & 4 & 7.54 & 11.5 \\
Fixed pigmented erythema & 3 & 5.66 & 5.66 \\
Lichenoid rash & 3 & 5.66 & 18 \\
Steven Johnson syndrome & 3 & 5.66 & 15.75 \\
Erythema multiform & 1 & 1.88 & 5 \\
Acute generalized & 1 & 1.88 & 2 \\
exanthematous pustulosis & & & \\
Prurigo & 1 & 1.88 & 7 \\
Urticaria & 1 & 1.88 & 2 \\
Phytophotodermatitis & 1 & 1.88 & 7 \\
Aggravated lichen planus & 1 & 1.88 & 7.5 \\
Aggravated bullous & 1 & 1.88 & 3 \\
pemphigoid & & & \\
Aggravated pemphigus & 1 & 1.88 & 7 \\
foliaceus & & & \\
Total & 53 & 100 & \\
\hline
\end{tabular}

positive in 11 cases, corresponding to the frequency of $35.48 \%$. Patients tested positively showed the following cutaneous adverse effects: systemic eczema

Table 3: Distribution of plant-induced cutaneous side effects

\begin{tabular}{|c|c|c|c|c|c|c|c|c|}
\hline Plant & SE & CE & ES & FPE & SJS & EM & AGEP & $\mathrm{Pr}$ \\
\hline $\begin{array}{l}\text { Detarium } \\
\text { microcarpum }\end{array}$ & 5 & 2 & 2 & & & 1 & & \\
\hline $\begin{array}{l}\text { Momordica } \\
\text { charantia }\end{array}$ & 2 & & 1 & & & & 1 & \\
\hline $\begin{array}{l}\text { Stereospermum } \\
\text { kunthianum }\end{array}$ & 2 & & & & 1 & & & \\
\hline $\begin{array}{l}\text { Jatropha } \\
\text { chevalieri }\end{array}$ & 1 & 2 & 1 & & & & & \\
\hline $\begin{array}{l}\text { Anogeissius } \\
\text { leiocarpus }\end{array}$ & 2 & & & 1 & & & & \\
\hline Acacia seyal & 1 & 1 & 1 & & & & & \\
\hline $\begin{array}{l}\text { Euphorbia } \\
\text { balsamifera }\end{array}$ & 2 & 1 & & & & & & 1 \\
\hline $\begin{array}{l}\text { Terminalia } \\
\text { avicennoïdes }\end{array}$ & 1 & & & & 1 & & & \\
\hline $\begin{array}{l}\text { Nauclea } \\
\text { latifolia }\end{array}$ & 1 & & & & & & & \\
\hline $\begin{array}{l}\text { Cassia } \\
\text { sieberiana }\end{array}$ & 1 & & & & & & & \\
\hline $\begin{array}{l}\text { Cassia } \\
\text { occidentalis }\end{array}$ & 1 & 1 & & & & & & \\
\hline $\begin{array}{l}\text { Leptadenia } \\
\text { hastate }\end{array}$ & 1 & 1 & & & & & & \\
\hline Euphorbia hirta & & & & & & & & 1 \\
\hline $\begin{array}{l}\text { Annona } \\
\text { senegalensis }\end{array}$ & & 1 & & & & & & \\
\hline $\begin{array}{l}\text { Securidata } \\
\text { longepe } \\
\text { dunculata }\end{array}$ & 1 & & & & & & & \\
\hline Nigella sativa & & & 1 & & & & & \\
\hline Acacia albida & 1 & & & & & & & \\
\hline $\begin{array}{l}\text { Securinega } \\
\text { virosa }\end{array}$ & 1 & & & & & & & \\
\hline $\begin{array}{l}\text { Mangifera } \\
\text { indica }\end{array}$ & 1 & & & & & & & \\
\hline Carapa procera & 1 & & & & & & & \\
\hline Aloe vera & 1 & & & & & & & \\
\hline $\begin{array}{l}\text { Anacardium } \\
\text { occidentale }\end{array}$ & & & 1 & & & & & \\
\hline $\begin{array}{l}\text { Xylopia } \\
\text { aethiopica }\end{array}$ & & & & 1 & & & & \\
\hline $\begin{array}{l}\text { Azadirachta } \\
\text { indica }\end{array}$ & 1 & & & & & & & \\
\hline $\begin{array}{l}\text { Sesamum } \\
\text { indicum }\end{array}$ & & & 1 & & & & & \\
\hline $\begin{array}{l}\text { Aphania } \\
\text { Senegalensis }\end{array}$ & 1 & & & & & & & \\
\hline $\begin{array}{l}\text { Fangara } \\
\text { zanthoxyloïdes }\end{array}$ & 1 & & & & & & & \\
\hline $\begin{array}{l}\text { Khaya } \\
\text { senegalensis }\end{array}$ & 1 & & & & & & & \\
\hline $\begin{array}{l}\text { Mitragyna } \\
\text { inermis }\end{array}$ & 1 & & & & & & & \\
\hline $\begin{array}{l}\text { Guiera } \\
\text { senegalensis }\end{array}$ & 1 & & & & & & & \\
\hline
\end{tabular}

SE: systemic eczema; CE: contact eczema; ES: erythrodermic syndrome; FPE: fixed pigmented erythroderma; SJS: Stevens-Johnson syndrome; EM: erythema multiform; AGEP: acute generalized exanthematous pustulosis; Pr: prurigo; Ur: urticaria. 
in 7 cases, Stevens-Johnson syndrome in 2 cases, contact eczema in 1 case, and fixed pigmented erythema in 1 case. Depending on the nature of the plant, patch tests were positive for Jatropha chevalieri $(\mathrm{n}=2)$, Terminalia avicennö̈de $(\mathrm{n}=2)$, Detarium microcarpum, Acacia seyal, Acacia albida, Acacia italic, Sesamum indicum, Mangifera indica, Momordica charantia, Nauclea latifolia, and Anogeisius leiocarpus (in one case each). No positive results were obtained for plant medicines in solution form. There was no statistically significant relationship between the type of cutaneous adverse effect and the test result $(\mathrm{p}=0.388)$ and between the nature of the plant used and the test result $(\mathrm{p}=0.402)$.

\section{DISCUSSION}

Studies on drug-test patches for cutaneous side effects related to herbal medicine are scarce. In a previous study from Senegal, Niang et al. reported 43 cases of cutaneous side effects related to medicinal plants, among which only 19 were tested by patches and pricks, with $62 \%$ and $26 \%$ positivity, respectively [5]. In India, out of 90 patients tested with patches, De et al. found a positivity rate of $26.7 \%$ [6].

Our study shows, once again, the high frequency and diversity of cutaneous reactions attributable exclusively to herbal medicine. This frequency is probably underestimated because of the systematic exclusion of patients who have simultaneously taken conventional drugs or in whom an interrogation did not initially establish the accountability of the plant.

Systemic eczema is the most common cutaneous side effect related to herbal medicine, observed in almost half of our patients. This result is in agreement with that obtained by Niang et al., in which systemic eczema accounted for $58 \%$ of cases [5]. In our study, plants most likely to cause systemic eczema were D. microcarpum, M. charantia, S. kunthianum, A. leiocarpus and E. balsamifera, D. microcarpum and S. kunthianum. These plants were found most conducive to systemic eczema also in the Niang et al. study, in addition to Guiera senegalensis. In the literature, cases of systemic eczema have also been reported with conventional drugs. The most frequently mentioned include amoxicillin, quinolones, acyclovir, and captopril $[7,8]$. In our research, no chemical similarities were found between conventional drugs and plants incriminated.
In view of these severe reactions, such as erythrodermic syndrome and Stevens-Johnson syndrome, which occurred in some of our patients, it becomes a necessity to improve the phytovigilance process. The high rate of positivity of patch tests observed in our study indicates their potentially significant contribution to the accountability process. Moreover, this rate could have been much higher if a late reading had been done at 96 hours or even a week. Nevertheless, a negative skin test does not exclude the relationship of a drug with the occurrence of a cutaneous reaction. The sensitivity of drug-test patches varies widely depending on the type of cutaneous reaction and the drug involved. Drug-test patches seem to help in exploring maculopapular exanthema, systemic eczema, acute generalized exanthematous pustulosis, and fixed drug eruption. Sensitivity is less important in the case of Lyell's and Stevens-Johnson syndromes: all of our 2 cases of Stevens-Johnson syndrome were positive. Patch tests are unhelpful in exploring vasculitis, urticaria, and angioedema [3]. Furthermore, the nature of the drug tested seems very important for the sensitivity of the drug-test patch $[3,4]$. The allergenic potential of plants needs no further demonstration. D. microcarpum contains in its composition coumarins, also present in the fragrance mix of the European Standard Series [9]. Meanwhile, M. charantia contains alpha-momorcharin, whose immunoallergenicity has already been demonstrated in rats [10]. Plants of the Euphorbiaceae family, such as J. chevelieri and E. balsamifera, contain sesquiterpenes known for their allergenic properties $[11,12]$.

In our series, systemic eczema gave a greater number of positive results, with 7 cases out of the 11 positive tests. In the series of Niang et al., 5 of the 10 positive tests were cases of systemic eczema [5]. The absence of a significant statistical link between the type of cutaneous reaction and the result of a patch test could be explained by the small size of our series.

\section{CONCLUSION}

In view of their high rate of positivity, patch tests can prove promising in the exploration of cutaneous side effects related to herbal medicine. However, further and broader studies are necessary in order to identify the main allergens in medicinal plants, which will improve the accountability process in cutaneous side effects related to herbal medicine. 


\section{ACKNOWLEDGEMENTS}

We would like to thank Said Turfe for proofreading this article.

\section{Statement of Human and Animal Rights}

All the procedures followed were in accordance with the ethical standards of the responsible committee on human experimentation (institutional and national) and with the 2008 revision of the Declaration of Helsinki of 1975.

\section{Statement of Informed Consent}

Informed consent for participation in this study was obtained from all patients.

\section{REFERENCES}

1. Union Africaine. Plan d'action de la décennie de la médecine traditionnelle (2001-2010). Mise en œuvre de la décision AHG/ DEC. 164 (XXXVII) de la conférence des chefs d'état et de gouvernement.

2. Crepy MN. [Occupational contact dermatitis in the agricultural sector]. Allergol Dermatol Profess. 2017;149:141-60.

3. Ahmad W, Latif I, Sheikh G, Hassan I, Rasool F, Keen A. Patch testing - Revisited. Our Dermatol Online. 2017;8:224-8.

4. Sekhon S, Nedorost ST. Patch testing for adverse drug reactions. Cutis. 2017;99:49-54.

5. Niang SO, Tine Y, Diatta BA, Diallo M, Fall M, Seck NB, et al.
Negative cutaneous effects of medicinal plants in Senegal. Br J Dermatol. 2015;173:26-9.

6. De D, Khullar G, Handa S. Performance of a commercially available plant allergen series in the assessment of suspected occupational contact dermatitis to plants in north Indian patients. Indian J Dermatol Venereol Leprol. 2015;81:376-9.

7. Özkaya E, Yazganoglu KD. Adverse cutaneous drug reactions to cardiovascular drugs. Springer-Verlag London. 2014;67.

8. Li BK, Tian EAL. Adverse drug reactions to oral antibiotics used for dermatological indications: a preliminary study. Ann Acad Med Singapore. 2014;1:S257.

9. Meda NR, Fraisse D, Gnoula C, Vivier M, Felgines C, Senejoux F. Characterization of antioxidants from Detarium microcarpum Guill. et Perr. leaves using HPLC-DAD coupled with pre-column DPPH assay. Europ Food Res Technol. Springer-Verlag Germany. 2017;243:1659-66.

10. Meng Y, Liu B, Lei N, Zheng J, He Q, Li D, et al. Alphamomorcharin possessing high immunogenicity, immunotoxicity and hepatotoxicity in SD rats. J Ethnopharmacol. 2012;139:590-8.

11. Salehi B, Iriti M, Vitalini S, Antolak H, Pawlikowska E, Kręgiel D, et al. Euphorbia-Derived natural products with potential for use in health maintenance. Biomolecules. 2019;9:337.

12. Paulsen E. Systemic allergic dermatitis caused by sesquiterpene lactones. Contact Dermatitis. 2017;76:1-10.

13. Johansen JD, Aalto-Korte K, Agner T, Andersen KE, Bircher A, Bruze M, et al. European Society of Contact Dermatitis guideline for diagnostic patch testing - recommendations on best practice. Contact Dermatitis. 2015;73:195-221.

Copyright by Birame Seck, et al. This is an open-access article distributed under the terms of the Creative Commons Attribution License, which permits unrestricted use, distribution, and reproduction in any medium, provided the original author and source are credited.

Source of Support: Nil, Conflict of Interest: None declared. 